\title{
Iron Content of Some Popular Cooked Foods Consumed by the Rural School Children in Sri Lanka
}

\author{
D. Ruwani G. Perera $\mathbb{D}^{1}{ }^{1}$ Dilantha Gunawardana, ${ }^{1}$ Renuka Jayatissa, ${ }^{2}$ \\ and A. Buddhika G. Silva $\mathbb{D}^{2}$ \\ ${ }^{1}$ Department of Botany, University of Sri Jayewardenepura, Nugegoda 10250, Sri Lanka \\ ${ }^{2}$ Department of Nutrition, Medical Research Institute, Borella 00800, Sri Lanka
}

Correspondence should be addressed to A. Buddhika G. Silva; buddhika-gayani@mri.gov.lk

Received 10 May 2019; Revised 26 August 2019; Accepted 1 October 2019; Published 3 November 2019

Academic Editor: Luis Patarata

Copyright ( 2019 D. Ruwani G. Perera et al. This is an open access article distributed under the Creative Commons Attribution License, which permits unrestricted use, distribution, and reproduction in any medium, provided the original work is properly cited.

\begin{abstract}
Iron is an important micronutrient that can be found in different food sources in varying quantities. Iron deficiency is common in populations consuming cereal-based diets with little or no animal-derived food products. Rice is the staple for Sri Lankans, which may not provide sufficient bioavailable iron. Sri Lankan food composition table does not contain data on iron in home-cooked foods. Aim of the present study was to determine the iron content in commonly consumed home-cooked foods (rice, vegetables, green leaves, pulses, fish, etc.) by children aged 15-16 years. The study was carried out in eight schools at the Divisional Secretariat, Horana. The average iron values of cooked rice, vegetables, green leaves, pulses, and fish were 23.29 $\pm 14.46,19.34 \pm 9.90$, $29.56 \pm 13.64,45.16 \pm 22.28$, and $46.72 \pm 14.53 \mathrm{mg} / \mathrm{kg}$, respectively. A serving of cooked red raw rice (rathu kekulu) provided the highest Estimated Daily Intake (EDI) of iron. The total EDI per serving for all categories was $6.39 \pm 1.06 \mathrm{mg}$, contributing to the recommended daily allowance (RDA) of $42.62 \%$ of girls and $58.12 \%$ of boys as defined by the United States Department of Agriculture. Meanwhile, based on the Sri Lankan RDA, dietary iron contribution per serving ranges from $16.39 \%$ to $17.76 \%$ in girls and $16.39 \%$ to $21.31 \%$ in boys in the $15-16$ years age category. Therefore, these home-cooked foods which were prepared using local recipes have high iron content and can replenish a major proportion of recommended quotidian values for iron intake.
\end{abstract}

\section{Introduction}

Micronutrient malnutrition is a widespread problem throughout the world $[1,2]$. Prevention of micronutrient malnutrition is a basic requirement in ensuring the rapid and appropriate national development [3-5]. The achievement and maintaining of the desirable level of nutritional quality in the national food supply is an important public health objective [3]. To achieve it, improving the dietary habits in the current society is a major challenge. An analytical assessment of the staple diet is necessary to identify healthy dietary strategies within the population. Iron is an important micronutrient [6-8], and it can cause ill effects with either lower or higher levels than the desired level $[4,9]$. Iron is found to be necessary in certain quantities in food and beverages including drinking water. Therefore, determination of iron content in food is essential for both food safety and nutritional considerations [7].

Sri Lankan staple diet is mainly based on plant-based food, and they are deficient in iron [4]. More than $40 \%$ of children, adolescent girls, and women of childbearing age including pregnant women are currently suffering from iron deficiency. In Sri Lanka, anaemia has become a moderate public health problem among preschool, nonpregnant, and pregnant populations as the prevalence are $33 \%, 39 \%$, and $34 \%$, respectively [4]. Iron deficiency anaemia is the most common type of anaemia throughout the world, and it is the common cause of nutritional anaemia in Sri Lanka as well [9].

The required amount of iron can be taken through iron supplements or by eating foods that are rich in iron [5]. Different food sources (plants or animals) contain iron in 
different quantities [5]. Depending on the cooking method, the iron content can be changed [5]. Furthermore, there is limited available knowledge on nutrient composition of the cooked foods in Sri Lanka [3]. Therefore, it is necessary to analyze the nutrient composition of cooked foods which are prepared according to the Sri Lankan domestic/local recipes. The results of this research can be used by the Ministry of Health, Sri Lanka, in policymaking and to increase public health awareness. The aim of this study was to analyze the iron content of selected commonly consumed cooked food among children aged 15-16 years of age.

\section{Materials and Methods}

2.1. Commonly Consumed Cooked Food by the Target Group. Data on food consumption were obtained by a 24 -h recall method among 36 boys and 36 girls in the Divisional Secretariat, Horana. Recalls were done for 3 consecutive days per person to capture weekdays and weekends for 2-month period. During the field visits, the recipes of commonly consumed cooked food including approximate amounts of ingredients used were recorded. When the same food was prepared using different recipes, the most popular recipe was used for the laboratory studies. Average portion size for each food item was obtained.

2.2. Sample Preparation. The required raw materials and ingredients were purchased from the retail shops and boutiques in the Horana area. All food items analyzed were cooked by using utensils which did not contain iron.

2.3. Determining Iron in Food Samples. Initially, the fresh weight of the sample was recorded. Each sample was dried in an oven for 3 days at $60^{\circ} \mathrm{C}$, and the dry weight was recorded. A representative portion from each cooked food sample was crushed to a fine homogeneous powder by using a blender. Each duplicate sample $(0.2500 \mathrm{~g})$ was digested using $3 \mathrm{~mL}$ of $69 \%-78 \%(\mathrm{w} / \mathrm{w})$ nitric acid and $1 \mathrm{~mL}$ of hydrogen peroxide (analytical grade) using a microwave digester. The clear digestion was brought up to $25 \mathrm{~mL}$ with deionized water, and they were analyzed in triplicates using a flame atomic absorption spectrophotometer (AAS) at a wavelength of $248.32 \mathrm{~nm}$. Calibration standard for iron was prepared using a stock of $1000 \mu \mathrm{g} \cdot \mathrm{mL}^{-1}$ using the serial dilution technique.

2.4. Quality Control. All glassware used in the assay was cleaned using detergent water, then rinsed with $5 \%$ nitric acid, then rinsed several times with deionized water, and was finally oven-dried. All plastic utensils were cleaned with detergent water, 5\% nitric acid, and deionized water, respectively. Then, they were allowed to dry under room temperature. Each batch of runs on the atomic absorption spectrophotometry (AAS) was standardized by running standard solutions. The method validation was done by spiking of known concentration of a standard solution with the known weight of the sample and then by estimating the recovery results.
2.5. Data Management and Statistical Analysis. The average iron content and estimated daily intake (EDI) of iron in each food item were recorded as the mean \pm standard deviation (SD). Comparison of the average iron content of each food type was performed orderly using one-way ANOVA in SPSS 23 software package. Statistical analysis was designed at $p<0.05$.

2.6. Estimated Daily Intake Per Serving. The daily intake of an element is a function of the concentration of the selected element in the food sample as well as the amount of food that is consumed daily. The estimated daily intake (EDI) was calculated using the following equation $[10,11]$ :

$$
\mathrm{EDI}=C \times M \text {, }
$$

where $C$ is the mean concentration of element (iron) in each food sample and $M$ refers to the assumed consumption rate $[10,11]$. In this research, consumption rate per person was assumed as the weight of one serving of each food (1 tablespoon for vegetable curries, green leaves, pulses, and recommended serving sizes for fish varieties [12]). The obtained values were then compared with the recommended daily allowances (RDA) of children aged $15-16$ years. RDA provides the information on average daily intake level that is sufficient to meet the nutrient requirements of nearly all (9798\%) healthy individuals in a particular life stage and a gender group, which is the standard value in assessing the adequacy of daily intake [13]. The values of the RDA for iron for the boys and girls in the 15-16 year age group are presented in Table 1 .

2.7. Contribution of Iron. The estimated contribution of various cooked foods to the daily intake of iron was therefore calculated using the following equation [16]:

Contribution to RDA per serving $=\frac{\text { EDI per serving }}{\mathrm{RDA}} \times 100 \%$.

\section{Results and Discussion}

The daily diet of the children comprised three main meals with different accompaniments. The composition of lunch and dinner was similar with rice and curry being the most popular choice. Rice is the staple food when considering main meals rather than wheat flour-based foods. Even though red raw rice (rathu kakulu haal) is popular as the most nutritious variety of rice available in Sri Lanka with a neutral flavor and good cooking qualities, it was not commonly consumed among the selected study population. Instead, white raw rice (sudu kekulu haal) and parboiled small rice grains (samba) were two of the more popular varieties among children.

The vegetables consumed were beetroot (Beta vulgaris), pumpkin (Cucurbita moschata), yellow cabbage (Brassera oleracea), ash plantain (Plantago lanceolata), potato (Solanum tuberosum), ladies' fingers (Abelmoschus esculentus), brinjal (Solanum melongena), and carrot (Daucus 
TABLE 1: RDA for iron in boys and girls in the 15-16 age range.

\begin{tabular}{lccc}
\hline Gender & RDA USDA $(\mathrm{mg} / \mathrm{d})[14]$ & \multicolumn{2}{c}{ RDA Sri Lanka $(\mathrm{mg} / \mathrm{d})[15]$} \\
& $15-16$ year age group & 15 years & 39 \\
Girls & 15 & 36 & 30 \\
Boys & 11 & 39 & 39 \\
\hline
\end{tabular}

$\mathrm{RDA}=$ recommended daily allowance; USDA = United States Department of Agriculture.

carota), while vegetable hummingbird (kathurumurunga) (Sesbania grandiflora), sessile joy weed (mukunuwenna) (Alternanthera sessilis), and centella (gotukola) (Centella asiatica) were the most commonly consumed green leafy vegetables. A considerable consumption was recorded regarding the nonvegetarian foods such as dried sprats (Stolephorus commersonii), salmon (Brand A), sardinella (salaya) (Sardinella gibbosa), Spanish mackerel (thora) (Scomberomorus commersoni), sailfish (thalapath) (Istiophorus platypterus), yellowfin tuna (kelawallo) (Thunnus albacares), red snapper (rathu gal malu) (Lutjanus argentimaculatus), and queenfish (kattawa) (Scomberoides commersonianus) were the most commonly consumed fish varieties. The most popular pulse varieties among the selected population were lentils and chickpeas which were also selected for the analysis.

While rice with a variety of vegetables, animal sources, and coconut sambol were frequent items in their main meals, wheat flour-based products and cereals were also included in the main meals from time to time. Commonly consumed popular foods among the children and their methods of preparation are described in Table 2.

3.1. Vegetables. Pumpkin curry contained a significantly higher amount of iron $(p<0.05)$ than the rest of the vegetable curries (Table 3 ). The iron content in the carrot curry was also significantly higher, and it is also higher than the iron content in raw carrots which had been reported by similar studies [17-19]. Except for the pumpkin and carrot curries, no significant difference was observed among the average iron contents of the other vegetable curries. Some studies reported that uncooked beetroot contains $3.7 \mathrm{mg} / \mathrm{kg}$ of iron [20], while pickled-drained beetroot contains $3 \mathrm{mg} /$ $\mathrm{kg}$ [17] and $5 \mathrm{mg} / \mathrm{kg}$ [18] of iron. Therefore, based on the present study, beetroot curry which was cooked according to the local recipe contained a higher amount of iron than raw and pickled-drained beetroot. Yellow cabbage curry has higher iron content than raw cabbage which had been reported in Bruggraber et al. [17], McCance and Widdowson [19], Narain and Ilango [21], and Gooneratne and Kumarapperuma [22]. Raw potato has $7.5 \mathrm{mg} / \mathrm{kg}$ [20] of iron while boiled potato has $8.5 \mathrm{mg} / \mathrm{kg}$ [17] of iron according to previous studies, while the current study reported a higher iron content in cooked potato compared with the above two. Higher iron content was found to be present in the brinjal curry compared with the value reported in Narin and Ilango $(3.16 \mathrm{mg} / \mathrm{kg})$ [21]. Therefore, the average iron contents of cooked vegetables were found to be higher than the amount present in raw vegetables.
3.2. Pulses. The most common type of pulse among the study population was lentil curry. It had a significantly higher iron content $(72.49 \pm 0.14 \mathrm{mg} / \mathrm{kg})$ than the rest (Table 3). A similar study reported the iron content in uncooked lentils to be $62.8 \pm 35.0 \mathrm{mg} / \mathrm{kg}$ [3], which is similar to cooked lentils. Daraniyagala and Gunawardena [5], Bruggraber et al. [17], McCance et al. [18], McCance and Widdowson [19], and Karunaratne et al. [23] reported much lower values for the iron content in lentils. Therefore, lentil curry can be considered as a good source of iron. No significant difference was found in the iron contents of the two chickpea samples prepared using different preparation methods. Previous studies revealed that the iron content in uncooked chickpea was $85.0 \pm 2 \mathrm{mg} / \mathrm{kg}$ [3] which is significantly higher than the iron content in cooked chickpea (Table 3). Karunaratne et al. [23] also reported a higher iron content in cooked chickpeas. Similar studies reported the iron content of boiled chickpea as $34.0 \pm 0.0 \mathrm{mg} / \mathrm{kg}$ [5] and cooked chickpea as $35.0 \pm 5 \mathrm{mg} /$ $\mathrm{kg}$ [5], which are in agreement with the current study. According to Bruggraber et al. [17], boiled chickpea had a lower iron content than chickpea curry, which is different from the result obtained in the current study. The iron content in cooked chickpea reported in Daraniyagala and Gunawardena [5] was similar to the present study.

3.3. Green Leaves. Centella (gotukola sambol) was found to be the best iron source $(45.12 \pm 8.33 \mathrm{mg} / \mathrm{kg})$ having a significantly higher average iron content $(p<0.05)$ compared with the other two types (Table 3), which are in accordance with the values reported in Gooneratne and Kumarapperuma [22], but not compatible to results obtained by Deraniyagala et al. [3]. Another study reported the mean iron content of selected fresh green leaves was $68.2 \pm 47.0 \mathrm{mg} / \mathrm{kg}$ and ranged from $35.6 \mathrm{mg} / \mathrm{kg}$ to $132 \mathrm{mg} / \mathrm{kg}$ [24]. Values reported in Anthony Swamy et al. [25] of uncooked green leafy vegetables ranged from 0.81 to $0.23 \mathrm{mg} / \mathrm{kg}$ and the cooked green leafy vegetables had iron levels ranging from 0.041 to $0.43 \mathrm{mg} / \mathrm{kg}$ while these results were not compatible with the present study [25].

3.4. Fish. The highest iron content in $1 \mathrm{~kg}$ of food sample was found in fried marinated sardinella (salaya) $(68.33 \pm 4.98 \mathrm{mg} / \mathrm{kg})$, which was significantly higher compared with the curries of other fish varieties (Table 3 ). The iron content obtained for sardinella (salaya) in the present study was compatible with the values reported by Wickramasinghe et al. [26]. Sardinella (salaya) curry also has a significantly higher iron content than the rest. Dried sprats have a significantly higher iron content than salmon (Brand 
TABLE 2: Commonly consumed foods by the study population and their respective methods of preparation.

\begin{tabular}{|c|c|c|}
\hline Food category & Food type & Method of preparation \\
\hline \multirow{8}{*}{ Vegetables } & Beetroot curry & $\begin{array}{l}\text { Cooked } 60 \mathrm{~g} \text { of small cut pieces using coconut milk } \\
(60 \mathrm{~g} \text { of coconut kernel), } 0.38 \mathrm{~g} \text { of chili powder, } 0.25 \\
\text { teaspoons (tsp) of curry powder }(0.5 \mathrm{~g}), 0.44 \mathrm{~g} \text { of } \\
\text { turmeric powder, onions, curry leaves }\end{array}$ \\
\hline & Pumpkin curry & $\begin{array}{l}\text { Cooked } 120 \mathrm{~g} \text { of small cut pieces using coconut milk } \\
(100 \mathrm{~g} \text { of coconut kernel), } 0.38 \mathrm{~g} \text { of chili powder, } 0.25 \\
\text { tsp of curry powder }(0.5 \mathrm{~g}), 0.44 \mathrm{~g} \text { of turmeric powder, } \\
\text { garlic, a small piece of cinnamon, black pepper, } \\
\text { onions, curry leaves }\end{array}$ \\
\hline & Yellow cabbage curry & Same as the beetroot curry \\
\hline & Ash plantain curry & $\begin{array}{l}\text { Cooked } 120 \mathrm{~g} \text { of small cut pieces using coconut milk } \\
\text { ( } 120 \mathrm{~g} \text { of coconut kernel), } 0.25 \text { tsp of curry powder } \\
(0.5 \mathrm{~g}), 0.25 \mathrm{tsp} \text { of chili powder }(0.67 \mathrm{~g}), 0.44 \mathrm{~g} \text { of } \\
\text { turmeric powder, a small piece of cinnamon, } \\
\text { fenugreek seeds, onions, curry leaves }\end{array}$ \\
\hline & Potato curry & Same as the ash plantain curry \\
\hline & Ladies' fingers curry & $\begin{array}{c}\text { Cooked } 120 \mathrm{~g} \text { of small cut pieces using coconut milk } \\
\text { ( } 120 \mathrm{~g} \text { of coconut kernel), } 0.25 \text { tsp of curry powder } \\
(0.5 \mathrm{~g}), 0.25 \mathrm{tsp} \text { of chili powder }(0.67 \mathrm{~g}), 0.44 \mathrm{~g} \text { of } \\
\text { turmeric powder, onions, curry leaves }\end{array}$ \\
\hline & Brinjal curry & $\begin{array}{l}\text { Cooked } 180 \mathrm{~g} \text { of small cut pieces using a small } \\
\text { amount of coconut oil, coconut milk ( } 60 \mathrm{~g} \text { of coconut } \\
\text { kernel), } 0.25 \mathrm{tsp} \text { of chili powder }(0.67 \mathrm{~g}), 0.5 \mathrm{tsp} \text { of } \\
\text { curry powder }(1.0 \mathrm{~g}), 0.25 \text { tsp of turmeric powder } \\
(0.77 \mathrm{~g}) \text {, onions, curry leaves }\end{array}$ \\
\hline & Carrot curry & Same as the brinjal curry \\
\hline \multirow{3}{*}{ Pulses } & Lentil curry & $\begin{array}{c}\text { Cooked } 80 \mathrm{~g} \text { using coconut milk ( } 100 \mathrm{~g} \text { of coconut } \\
\text { kernel), } 0.5 \text { tsp of chili powder }(1.35 \mathrm{~g}), 0.5 \mathrm{tsp} \text { of } \\
\text { curry powder }(1 \mathrm{~g}), 0.25 \text { tsp of turmeric powder } \\
(0.77 \mathrm{~g}) \text {, onions, curry leaves }\end{array}$ \\
\hline & Chickpea curry & $\begin{array}{c}\text { Cooked } 150 \mathrm{~g} \text { using coconut milk }(200 \mathrm{~g} \text { of coconut } \\
\text { kernel), } 0.25 \mathrm{tsp} \text { of chili powder }(0.67 \mathrm{~g}), 0.5 \mathrm{tsp} \text { of } \\
\text { curry powder }(1 \mathrm{~g}), 0.44 \mathrm{~g} \text { of turmeric powder, onions, } \\
\text { curry leaves }\end{array}$ \\
\hline & Chickpeas boiled & Cooked $200 \mathrm{~g}$ using water \\
\hline \multirow{3}{*}{ Green leaves } & Sessile joy weed (mukunuwenna) & $\begin{array}{c}\text { Cooked } 60 \mathrm{~g} \text { of cut leaves with } 15 \mathrm{~g} \text { of coconut } \\
\text { scrapings along with } 0.25 \text { tsp of turmeric powder } \\
(0.77 \mathrm{~g}) \text {, small pieces of green chilies, onions, curry } \\
\text { leaves }\end{array}$ \\
\hline & Centella (gotukola) & $\begin{array}{c}\text { Mixed } 60 \mathrm{~g} \text { of cut leaves with } 15 \mathrm{~g} \text { of coconut } \\
\text { scrapings along with small pieces of green chilies, } \\
\text { onions, lemon juice }\end{array}$ \\
\hline & Vegetable hummingbird (kathurumurunga) & Same as the mukunuwenna malluma. \\
\hline
\end{tabular}


TABLE 2: Continued.

\begin{tabular}{|c|c|c|}
\hline Food category & Food type & Method of preparation \\
\hline \multirow{9}{*}{ Fish } & Dried sprats curry & $\begin{array}{l}\text { Cooked } 40 \mathrm{~g} \text { using coconut milk ( } 120 \mathrm{~g} \text { of coconut } \\
\text { scrapings), } 1 \text { tsp of curry powder }(2 \mathrm{~g}), 2 \mathrm{tsp} \text { of chili } \\
\text { powder }(5.4 \mathrm{~g}), 0.25 \text { tsp of turmeric powder }(0.77 \mathrm{~g}) \\
\text { curry leaves, onions, green chilies }\end{array}$ \\
\hline & Salmon (brand A) curry & $\begin{array}{l}\text { Cooked } 50 \mathrm{~g} \text { using coconut milk ( } 150 \mathrm{~g} \text { of coconut } \\
\text { scrapings), } 1.25 \text { tsp of curry powder }(2.5 \mathrm{~g}), 2 \text { tsp of } \\
\text { chili powder ( } 5.4 \mathrm{~g}), 0.5 \text { tsp of turmeric powder } \\
(1.55 \mathrm{~g}), \text { curry leaves, onions, green chilies }\end{array}$ \\
\hline & Sardinella (salaya) fried marinated & $\begin{array}{c}\text { Mixed well with } 0.25 \text { tsp of turmeric powder }(0.77 \mathrm{~g}) \\
\text { and then deep-fried in coconut oil }\end{array}$ \\
\hline & Sardinella (salaya) curry & $\begin{array}{c}\text { Cooked } 40 \mathrm{~g} \text { using coconut milk ( } 120 \mathrm{~g} \text { of coconut } \\
\text { scrapings), } 1 \mathrm{tsp} \text { of curry powder }(2 \mathrm{~g}), 2 \mathrm{tsp} \text { of chili } \\
\text { powder }(5.4 \mathrm{~g}), 0.25 \mathrm{tsp} \text { of turmeric powder }(0.77 \mathrm{~g}) \\
\text { curry leaves, onions, green chilies }\end{array}$ \\
\hline & Spanish mackerel (thora) curry & $\begin{array}{c}\text { Cooked } 80 \mathrm{~g} \text { using coconut milk ( } 80 \mathrm{~g} \text { of coconut } \\
\text { scrapings), } 1 \text { tsp of curry powder }(2 \mathrm{~g}), 1 \mathrm{tsp} \text { of chili } \\
\text { powder }(2.7 \mathrm{~g}), 0.25 \mathrm{tsp} \text { of turmeric powder }(0.77 \mathrm{~g}) \\
\text { curry leaves, onions, green chilies }\end{array}$ \\
\hline & Sail fish (thalapath) curry & $\begin{array}{l}\text { Cooked } 100 \mathrm{~g} \text { using coconut milk ( } 80 \mathrm{~g} \text { of coconut } \\
\text { scrapings), } 1.5 \text { tsp of chili powder }(4.05 \mathrm{~g}), 1 \text { tsp of } \\
\text { curry powder }(2 \mathrm{~g}), 0.25 \text { tsp of turmeric powder } \\
(0.77 \mathrm{~g}), \text { curry leaves, onions, green chilies }\end{array}$ \\
\hline & Yellowfin tuna (kelawallo) curry & As for the thalapath curry \\
\hline & Red snapper (rathu gal malu) curry & $\begin{array}{c}\text { Cooked } 40 \mathrm{~g} \text { using coconut milk ( } 120 \mathrm{~g} \text { of coconut } \\
\text { scrapings), } 2 \text { tsp of chili powder }(5.4 \mathrm{~g}), 1 \mathrm{tsp} \text { of curry } \\
\text { powder }(2 \mathrm{~g}), 0.25 \mathrm{tsp} \text { of turmeric powder }(0.77 \mathrm{~g}) \text {, } \\
\text { curry leaves, onions, green chilies }\end{array}$ \\
\hline & Queen fish (kattawa) curry & $\begin{array}{l}\text { Cooked } 20 \mathrm{~g} \text { using coconut milk ( } 120 \mathrm{~g} \text { of coconut } \\
\text { scrapings), } 0.5 \text { tsp of chili powder }(1.35 \mathrm{~g}), 0.25 \text { tsp of } \\
\text { turmeric powder }(0.77 \mathrm{~g}), 1 / 6 \text { tsp of fenugreek seeds, } \\
\text { curry leaves, onions, green chilies }\end{array}$ \\
\hline \multirow{3}{*}{ Rice } & White raw rice (sudu kekulu) & Cooked with water \\
\hline & Red raw rice (rathu kekulu) & Cooked with water \\
\hline & Parboiled small rice (samba) & Cooked with water \\
\hline \multirow[b]{2}{*}{ Other foods } & Coconut sambol & $\begin{array}{c}\text { Spicy coconut preparation using the scraped coconut } \\
\text { kernel }\end{array}$ \\
\hline & String hoppers & $\begin{array}{c}\text { String hoppers (wheat flour) were taken from two } \\
\text { boutiques in the Divisional Secretariat Division, } \\
\text { Horana }\end{array}$ \\
\hline
\end{tabular}

For all food items, salt was added for taste. Onions, green chilies, and curry leaves were added in equal quantities for all food items as $11.5 \mathrm{~g}, 4 \mathrm{~g}$, and $2 \mathrm{~g}$, respectively. Weight of $1 \mathrm{tsp}$ of turmeric powder $=3.1 \mathrm{~g}$, weight of $1 \mathrm{tsp}$ of chili powder $=2.7 \mathrm{~g}$, and weight of $1 \mathrm{tsp}$ of curry powder $=2 \mathrm{~g}$.

A) and yellowfin tuna (kelawallo) curries. Karunaratne et al. [23] reported an iron content of $17.9 \pm 0.6 \mathrm{mg} / \mathrm{kg}$ in dried sprats which was less than the value obtained in the present study.

3.5. Rice. All rice varieties consumed by the studied population were local origin, and the popular varieties were red raw rice (rathu kekulu), white raw rice (sudu kekulu), and parboiled small rice grains (samba). The iron levels of these three varieties ranged from 5.74 to $36.92 \mathrm{mg} / \mathrm{kg}$ (Table 3) while data obtained from similar studies reported values ranging from 20 to $35 \mathrm{mg} / \mathrm{kg}$ [7]. The iron content obtained for rice samples in the present study was compatible with the values reported by Rajbandari and Subedi [7] and Liang [27]. According to Deraniyagala et al. [3], raw samba and raw rathu kekulu had lower iron content than cooked samba and rathu kekulu, which is different from the results obtained in the present study. Higher iron contents were found to be present in the cooked rice varieties compared with the values reported in Karuratane et al. [23]. The level of iron was significantly higher in rathu kekulu $(36.92 \pm 1.37 \mathrm{mg} /$ $\mathrm{kg})$ compared with samba $(p=0.014,95 \%$ confident interval), and there was no significant difference between the average iron content of cooked rathu kekulu and cooked sudu kekulu varieties.

3.6. Other Foods. Wheat flour consumption among the selected population was done in two ways, not leavened (as string hoppers) or leavened (as buns or bread). Based on the present study, the iron content of string hoppers (wheat flour) was $28.26 \pm 2.78 \mathrm{mg} / \mathrm{kg}$ (Table 3 ) while $0.34 \pm 0.033 \mathrm{mg}$ 
TABle 3: Average iron content of cooked food varieties consumed by the adolescents (15-16 years) in the Divisional Secretariat, Horana.

\begin{tabular}{|c|c|c|}
\hline Type & Iron content $(\mathrm{mg} / \mathrm{kg})$ & SD \\
\hline \multicolumn{3}{|l|}{ Vegetables } \\
\hline Beetroot curry & 21.46 & 0.07 \\
\hline Pumpkin curry & 38.79 & 0.37 \\
\hline Yellow cabbage curry & 18.20 & 0.23 \\
\hline Ash plantain curry & 9.83 & 0.31 \\
\hline Potato curry & 15.66 & 1.26 \\
\hline Ladies' finger curry & 7.61 & 0.24 \\
\hline Brinjal curry & 15.36 & 6.43 \\
\hline Carrot curry & 27.80 & 0.18 \\
\hline \multicolumn{3}{|l|}{ Pulses } \\
\hline Lentil curry & 72.49 & 0.14 \\
\hline Chickpea boiled & 36.37 & 9.00 \\
\hline Chickpea curry & 26.64 & 8.10 \\
\hline \multicolumn{3}{|l|}{ Green leaves } \\
\hline Sessile joy weed (mukunuwenna malluma) & 17.14 & 4.23 \\
\hline Centella (gotukola sambol) & 45.12 & 8.33 \\
\hline Vegetable hummingbird (kathurumurunga malluma) & 26.42 & 5.58 \\
\hline \multicolumn{3}{|l|}{ Fish } \\
\hline Dried sprats curry & 57.18 & 3.32 \\
\hline Salmon (brand A) curry & 27.74 & 1.18 \\
\hline Sardinella (salaya) fried marinated & 68.33 & 4.98 \\
\hline Sardinella (salaya) curry & 60.46 & 3.43 \\
\hline Spanish mackerel (thora) curry & 41.42 & 2.35 \\
\hline Sailfish (thalapath) curry & 47.02 & 6.06 \\
\hline Yellowfin tuna (kelawallo) curry & 24.17 & 5.40 \\
\hline Red snapper (rathu gal malu) curry & 43.17 & 8.13 \\
\hline Queenfish (kattawa) curry & 50.93 & 4.23 \\
\hline \multicolumn{3}{|l|}{ Rice } \\
\hline White raw rice (sudu kekulu) boiled & 27.22 & 2.05 \\
\hline Red raw rice (rathu kekulu) boiled & 36.92 & 1.37 \\
\hline Parboiled small rice (samba) boiled & 5.74 & 4.53 \\
\hline \multicolumn{3}{|l|}{ Other foods } \\
\hline Coconut sambol & 30.68 & 1.45 \\
\hline String hoppers & 28.26 & 2.78 \\
\hline
\end{tabular}

of iron can be obtained per serving (12 g; 1 string hopper). Scraped coconut kernel sambol/coconut sambol was used as an accompaniment to string hoppers as well as rice. The average iron content of $30.68 \pm 1.45 \mathrm{mg}$ was found in $1 \mathrm{~kg}$ of coconut kernel sambol (Table 3), while it provided $0.77 \pm 0.036 \mathrm{mg}$ of iron per serving $(1 \mathrm{tbs}=25 \mathrm{~g})$. A similar study reported the iron content of the combination of string hoppers (wheat flour) and coconut sambol to be $26.6 \pm 2.8 \mathrm{mg} / \mathrm{kg}$ (dry weight) [23]. The iron content of uncooked scraped coconut kernel sambol was reported to be $29.4 \pm 1.5 \mathrm{mg} / \mathrm{kg}$ [23] which is compatible with the present study.

Based on the USDA guidelines, children in 14-18 years of age in the adolescent age group required the highest amount of RDA [14]. In contrast, based on SL RDA, 15-16 years of children required the highest amount of iron $(30 \mathrm{mg}$ and $36 \mathrm{mg}$ for 15-year-old boys and girls, respectively, while $39 \mathrm{mg}$ for 16-year-old boys as well as girls) [15]. Meanwhile, boys and girls in the 15-16 age group were referred as upper secondary students, and they have to prepare for the G. C. E Ordinary Level examination successfully which is conducted by the Sri Lankan government to achieve their goals in further education. Therefore, the nutritional status of the children in this age group is a necessary factor for themselves and also for the public at large. The selected homemade foods for the analysis were the most popular ones among these children, and the percentage contributions of these foods to their RDAs of iron are summarized in Table 4.

3.7. Vegetable Curries. The highest iron content per serving can be obtained by pumpkin curry $(1.16 \pm 0.011 \mathrm{mg})$. The mean estimated iron intake that can be obtained through these eight vegetable curries was $0.52 \pm 0.30 \mathrm{mg}$ per serving (Table 4). Based on the USDA guidelines, this contributes to $3.45 \%$ and $4.70 \%$ of the daily requirement of boys and girls, respectively, in the age group 15-16 years. However, based on the Sri Lankan guidelines, this estimated daily intake of iron per serving contributes to $1.44 \%, 1.33 \%, 1.72 \%$, and $1.33 \%$ of the daily requirement of 15 -year-old girls, 16 -yearold girls, 15-year-old boys, and 16-year-old boys, respectively (Table 4). Contribution to the RDA by estimated average intake per serving was found to be higher in boys than in girls. 
TABLE 4: Estimated daily intake of iron per serving of each food item and its contribution to RDA.

\begin{tabular}{|c|c|c|c|c|c|c|c|c|}
\hline & \multirow{3}{*}{$\begin{array}{l}\text { Serving } \\
\text { size }(\mathrm{kg})\end{array}$} & \multirow{3}{*}{$\begin{array}{c}\text { EDI per } \\
\text { serving }(\mathrm{mg})\end{array}$} & \multicolumn{6}{|c|}{ Contribution to the RDA per serving (\%) } \\
\hline & & & \multicolumn{2}{|c|}{$\begin{array}{l}\text { Based on the USDA } \\
\text { guidelines }\end{array}$} & \multicolumn{4}{|c|}{ Based on the SL guidelines } \\
\hline & & & $\begin{array}{l}\text { Girls } 15-16 \\
\text { years }\end{array}$ & $\begin{array}{l}\text { Boys } 15-16 \\
\text { years }\end{array}$ & $\begin{array}{l}\text { Girls } 15 \\
\text { years }\end{array}$ & $\begin{array}{l}\text { Girls } 16 \\
\text { years }\end{array}$ & $\begin{array}{l}\text { Boys } 15 \\
\text { years }\end{array}$ & $\begin{array}{c}\text { Boys } 16 \\
\text { years }\end{array}$ \\
\hline \multicolumn{9}{|l|}{ (1) Vegetables } \\
\hline Beetroot curry & 0.025 & $0.54 \pm 0.002$ & 3.58 & 4.88 & 1.49 & 1.38 & 1.79 & 1.38 \\
\hline Pumpkin curry & 0.030 & $1.16 \pm 0.011$ & 7.76 & 10.58 & 3.23 & 2.98 & 3.88 & 2.98 \\
\hline Yellow cabbage curry & 0.025 & $0.46 \pm 0.006$ & 3.03 & 4.14 & 1.26 & 1.17 & 1.52 & 1.17 \\
\hline Ash plantain curry & 0.025 & $0.25 \pm 0.008$ & 1.64 & 2.23 & 0.68 & 0.63 & 0.82 & 0.63 \\
\hline Potato curry & 0.025 & $0.39 \pm 0.031$ & 2.61 & 3.56 & 1.09 & 1.00 & 1.31 & 1.00 \\
\hline Ladies' finger curry & 0.025 & $0.19 \pm 0.006$ & 1.27 & 1.73 & 0.53 & 0.49 & 0.63 & 0.49 \\
\hline Brinjal curry & 0.030 & $0.46 \pm 0.193$ & 3.07 & 4.19 & 1.28 & 1.18 & 1.54 & 1.18 \\
\hline Carrot curry & 0.025 & $0.69 \pm 0.004$ & 4.63 & 6.32 & 1.93 & 1.78 & 2.32 & 1.78 \\
\hline Mean & 0.026 & $0.52 \pm 0.30$ & 3.45 & 4.70 & 1.44 & 1.33 & 1.72 & 1.33 \\
\hline \multicolumn{9}{|l|}{ (2) Pulses } \\
\hline Lentil curry & 0.030 & $2.17 \pm 0.004$ & 14.50 & 19.77 & 6.04 & 5.58 & 7.25 & 5.58 \\
\hline Chickpea boiled & 0.021 & $0.76 \pm 0.189$ & 5.09 & 6.94 & 2.12 & 1.96 & 2.55 & 1.96 \\
\hline Chickpea curry & 0.025 & $0.67 \pm 0.202$ & 4.44 & 6.05 & 1.85 & 1.71 & 2.22 & 1.71 \\
\hline Mean & 0.025 & $1.20 \pm 0.765$ & 8.01 & 10.92 & 3.34 & 3.08 & 4.00 & 3.08 \\
\hline \multicolumn{9}{|l|}{ (3) Green leaves } \\
\hline $\begin{array}{l}\text { Sessile joy weed (mukunuwenna } \\
\text { malluma) }\end{array}$ & 0.010 & $0.17 \pm 0.042$ & 1.14 & 1.56 & 0.48 & 0.44 & 0.57 & 0.44 \\
\hline Centella (gotukola sambol) & 0.013 & $0.59 \pm 0.108$ & 3.91 & 5.33 & 1.63 & 1.50 & 1.96 & 1.50 \\
\hline $\begin{array}{l}\text { Vegetable hummingbird } \\
\text { (kathurumurunga malluma) }\end{array}$ & 0.010 & $0.26 \pm 0.056$ & 1.76 & 2.40 & 0.73 & 0.68 & 0.88 & 0.68 \\
\hline Mean & 0.011 & $0.34 \pm 0.203$ & 2.27 & 3.10 & 0.95 & 0.87 & 1.14 & 0.87 \\
\hline \multicolumn{9}{|l|}{ (4) Fish } \\
\hline Dried sprats curry & 0.015 & $0.86 \pm 0.05$ & 5.72 & 7.80 & 2.38 & 2.20 & 2.86 & 2.20 \\
\hline Salmon (brand A) curry & 0.030 & $0.83 \pm 0.035$ & 5.55 & 7.57 & 2.31 & 2.13 & 2.77 & 2.13 \\
\hline Sardinella (salaya) fried marinated & 0.030 & $2.05 \pm 0.15$ & 13.67 & 18.64 & 5.69 & 5.26 & 6.83 & 5.26 \\
\hline Sardinella (salaya) curry & 0.030 & $1.81 \pm 0.103$ & 12.09 & 16.49 & 5.04 & 4.65 & 6.05 & 4.65 \\
\hline Spanish mackerel (thora) curry & 0.030 & $1.24 \pm 0.071$ & 8.28 & 11.30 & 3.45 & 3.19 & 4.14 & 3.19 \\
\hline Sailfish (thalapath) curry & 0.030 & $1.41 \pm 0.182$ & 9.40 & 12.82 & 3.92 & 3.62 & 4.70 & 3.62 \\
\hline Yellowfin tuna (kelawallo) curry & 0.030 & $0.73 \pm 0.162$ & 4.83 & 6.59 & 2.01 & 1.86 & 2.42 & 1.86 \\
\hline Red snapper (rathu gal malu) curry & 0.030 & $1.30 \pm 0.244$ & 8.63 & 11.77 & 3.60 & 3.32 & 4.32 & 3.32 \\
\hline Queenfish (kattawa) curry & 0.030 & $1.53 \pm 0.127$ & 10.19 & 13.89 & 4.24 & 3.92 & 5.09 & 3.92 \\
\hline Mean & 0.028 & $1.31 \pm 0.45$ & 8.71 & 11.87 & 3.63 & 3.35 & 4.35 & 3.35 \\
\hline \multicolumn{9}{|l|}{ (5) Rice varieties } \\
\hline White raw rice (sudu kekulu) & 0.130 & $3.54 \pm 0.267$ & 23.59 & 32.17 & 9.83 & 9.07 & 11.80 & 9.07 \\
\hline Red raw rice (rathu kekulu) & 0.130 & $4.80 \pm 0.178$ & 32.00 & 43.63 & 13.33 & 12.31 & 16.00 & 12.31 \\
\hline Parboiled small rice (samba) & 0.130 & $0.75 \pm 0.589$ & 4.97 & 6.78 & 2.07 & 1.91 & 2.49 & 1.91 \\
\hline Mean & 0.130 & $3.03 \pm 1.880$ & 20.19 & 27.53 & 8.41 & 7.76 & 10.09 & 7.76 \\
\hline \multicolumn{9}{|l|}{ (6) Other foods } \\
\hline Coconut sambol & 0.250 & $0.77 \pm 0.036$ & 5.11 & 6.97 & 2.13 & 1.97 & 2.56 & 1.97 \\
\hline String hopper & 0.120 & $0.34 \pm 0.033$ & 2.26 & 3.08 & 0.94 & 0.87 & 1.13 & 0.87 \\
\hline
\end{tabular}

Values of estimated daily intake per serving are mean $\pm \mathrm{SD}(n=2)$; EDI $=$ estimated daily intake, $\mathrm{RDA}=$ recommended daily allowance, USDA $=$ United States Department of Agriculture, and SL=Sri Lanka; Serving size-vegetables, pulses, green leaves, and coconut sambol: 1 tablespoon (tbs); rice: 1 teacup; fish varieties: based on the food-based dietary guidelines [12]; string hoppers $=1$ string hopper.

3.8. Pulses. The highest estimated average intake of iron per serving can be obtained from lentil curry $(2.17 \pm 0.004 \mathrm{mg})$. Mean iron content of $1.20 \pm 0.77 \mathrm{mg}$ per serving can be obtained from the selected cooked pulses (Table 4). Based on the USDA guidelines, it contributes to $8.01 \%$ and $10.92 \%$ of the recommended daily requirement of girls and boys, respectively. Based on the SL guidelines, it contributes to $3.34 \%$ and $3.08 \%$ of the recommended daily requirement of girls in the age group 15 and 16 years and $4.00 \%$ and 3.08\% of the recommended daily requirement of boys in the same age group (Table 4).

3.9. Green Leaves. A mean iron content of $0.34 \pm 0.203 \mathrm{mg}$ can be obtained per serving from the selected green leaves (Table 4). Based on the USDA guidelines, it contributes to $2.27 \%$ and $3.10 \%$ of the daily iron requirement of girls and boys, respectively. Based on the SL guidelines, it only 
contributes to $0.95 \%, 0.87 \%, 1.14 \%$, and $0.87 \%$ of the daily requirement of 15-year-old girls, 16-year-old girls, 15-yearold boys, and 16-year-old boys, respectively (Table 4). The total iron content of these green leaf samples was dependent on the preparation method. However, green leafy vegetables are considered as a good source of iron in Sri Lankan diet, particularly among the populations that are largely dependent on a plant-based diet [24].

3.10. Fish. The highest iron content which is $2.05 \mathrm{mg}$ can be obtained by marinated salaya per serving $(0.030 \mathrm{~kg})$. A mean iron content of $1.31 \pm 0.45 \mathrm{mg}$ per serving can be obtained from the selected fish varieties (Table 4). Based on the USDA guidelines, it contributes to $8.71 \%$ and $11.87 \%$ of the recommended daily requirement of girls and boys in the 15-16 age category. According to the SL guidelines, it only contributes to $3.63 \%, 3.35 \%, 4.35 \%$, and $3.35 \%$ of the daily iron requirement of 15-year-old girls, 16-year-old girls, 15-yearold boys, and 16-year-old boys, respectively (Table 4).

3.11. Rice. The serving size of rice was represented by one teacup [12], and the average iron content which can be obtained through these three rice varieties was $3.03 \pm 1.88 \mathrm{mg}$ per serving (Table 4). Based on the USDA guidelines, the average estimated daily intake per serving contributes to $20.19 \%$ of the recommended daily allowance of girls and $27.53 \%$ of the recommended daily allowance of boys. According to the SL guidelines, it contributes to $8.41 \%$, $7.76 \%, 10.09 \%$, and $7.76 \%$ of the recommended daily allowances of 15-year-old girls, 16-year-old girls, 15-year-old boys, and 16-year-old boys, respectively (Table 4).

A considerable amount of iron can be obtained through the selected foods which were cooked according to the domestic/local recipes in Sri Lanka. The amount of iron in these cooked food samples was higher than that of raw foods. To prepare these food items according to the domestic/local recipes, several spices and other condiments must be added to enhance the taste. The chili powder (iron: $174 \mathrm{mg} / \mathrm{kg}$ [28] and $1.07 \mathrm{mg} / 1$ tbs [29]), curry powder (iron: $190 \mathrm{mg} / \mathrm{kg}$ [28] and $1.86 \mathrm{mg} / 1$ tbs [29]), turmeric powder (iron: $550 \mathrm{mg} / \mathrm{kg}$ [28] and $2.82 \mathrm{mg} / 1$ tbs [29]), salt (iron: $0.06 \mathrm{mg} / 1$ tbs [29]), black paper (iron: $96 \mathrm{mg} / \mathrm{kg}$ [28], $85.73 \mathrm{mg} / \mathrm{kg}$ [21] and 1.85/ 1 tbs [29]), cinnamon (iron: $0.65 \mathrm{mg} / 1$ tbs [29]), fenugreek seed (iron: $3.72 \mathrm{mg} / 1 \mathrm{tbs}$ [29]), onion (iron: $4.3 \mathrm{mg} / \mathrm{kg}$ [17], $3 \mathrm{mg} / \mathrm{kg}$ [18], $3 \mathrm{mg} / \mathrm{kg}$ [19], and $958 \mathrm{mg} / \mathrm{kg}$ [30]), curry leaves, green chili (iron: $9.79 \mathrm{mg} / \mathrm{kg}$ [21]), and garlic (iron: $58 \mathrm{mg} / \mathrm{kg}$ [28] and $0.23 \mathrm{mg} / 1$ tbs [29]) are usually added as spices/condiments to prepare the meals in domestic/local recipes. Even though the fractional contribution of spices and sourcing agents was negligible, they provide a significant contribution to the total iron content because of the high iron compaction [21]. In some studies, contribution to dietary iron by spices and condiments was found to be $56 \%$, and it provides the highest contribution to the total iron content in cooked food [21].

The total iron content of each cooked food sample is governed by the preparation method (Table 2) as well as the iron content of spices and other condiments, iron in coconut milk [5], source of used water (groundwater $0.5-22.5 \mathrm{mg} / \mathrm{L}$ [7] and tap water $2.6 \times 10^{-1} \mathrm{mg} / \mathrm{kg}$ [21]), utensils (knives and pans $[5,18])$, soil particles $[3,18]$, and processing machinery [18]. Coconut in different forms (scraped kernel, milk, and oil) was commonly used in most preparations and considered as an integral part of Sri Lankan dishes [23]. The iron content of coconut kernel was $29.74 \mathrm{mg} / \mathrm{kg}$ [31], while Santos et al (2014) [32] reported the coconut milk has iron content ranging from $0.76 \mathrm{mg} / \mathrm{kg}$ to $5.52 \mathrm{mg} / \mathrm{kg}$ and provided a considerable contribution to the iron content in cooked foods such as curries and green leaves (malluma).

The total average EDI per serving of rice, vegetables, pulses, green leaves, and fish was $6.39 \pm 1.06 \mathrm{mg}$; based on the USDA guidelines, it contributes to $42.62 \%$ and $58.12 \%$ of the RDA of girls and boys, respectively. According to the SL guidelines, the same iron content contributed to $17.76 \%$ and $16.39 \%$ of the RDA of girls in the age group 15 and 16 years and $21.31 \%$ and $16.39 \%$ of the RDA of boys in the same age group. Usually, they consumed more than one serving of them. Therefore, the iron contribution to the RDA of boys and girls aged 15-16 years was fulfilled by these cooked food items. A similar study was carried out by Hettiarachchi et al. [33] to assess the daily dietary intake, and they found that the mean iron intakes were $11.5 \pm 1.0 \mathrm{mg} /$ day and $11.4 \pm 1.0 \mathrm{mg} /$ day among boys and girls, respectively.

Even though the dietary iron of these cooked foods contributed to the daily iron intake, the total amount of iron consumed may not be absorbed into the body. The measured total iron content of this study is referred to as the sum of all the freely available ferric $\left(\mathrm{Fe}^{3+}\right)$ and ferrous $\left(\mathrm{Fe}^{2+}\right)$ together with the iron complexes available in the food sample. At the wavelength of $248.32 \mathrm{~nm}$, all the $\mathrm{Fe}^{2+}, \mathrm{Fe}^{3+}$ (nonheme iron), and iron in complexes (heme iron) in the food sample were measured (using the given procedure for iron analysis in this study, all the $\mathrm{Fe}^{2+}$ ions were converted to $\mathrm{Fe}^{3+}$ by $\mathrm{HNO}_{3}$ and $\mathrm{H}_{2} \mathrm{O}_{2}$ ) [34].

However, the total iron content may not be absorbed by the body; thus, freely available ferrous ions and heme iron are the more bioavailable forms compared with ferric ions in the nonheme iron group [34]. Meanwhile, the absorption of iron from the meal depends on several factors such as the individual's iron status and requirement $[35,36]$, nature of the sources of iron [37], total iron content within the meal [37], amount of iron released, and the other associated constituents of the meal [38]. Iron deficiency results when the amount of dietary iron absorbed is insufficient to meet the daily iron requirement of an individual.

\section{Conclusions}

The meals among the selected study population mainly consisted of rice-based meals with vegetable accompaniments. Lentil curry is the best source of iron among the tested foods. Pumpkin curry has the highest iron content among selected vegetable curries, and centella (gotukola sambol) also contains high iron compaction. Fried marinated sardinella (salaya) provides the highest iron content among selected cooked fish varieties. Red raw rice (rathu kekulu) is also a good source of iron than parboiled small 
grain rice (samba) and white raw rice (sudu kekulu) varieties. Scraped coconut kernel sambol is used as a popular accompaniment, and it also has considerable iron compaction. The cooked fish category is the best source of iron than the rest.

These cooked food types which are prepared in local/ domestic recipes have higher iron content than raw foods, and they can fulfill the considerable proportion of the daily iron requirement of girls and boys in the 15-16 age category, even by a single serving.

\section{Data Availability}

The raw data can be received from the corresponding author upon request.

\section{Conflicts of Interest}

The authors declare that they have no conflicts of interest.

\section{Acknowledgments}

The study was made possible with the support of the Department of Nutrition, Medical Research Institute, Sri Lanka, and the Department of Botany and Instrument Centre at the University of Sri Jayewardenepura, Sri Lanka.

\section{References}

[1] Food and Agricultural Organization of the United Nations/ World Health Organization, Requirements of Vitamin A, Iron, Folate and Vitamin B12: Report of a Joint of FAO/WHO Expert Consultation, Food and Agriculture Organization, Rome, Italy, 1988.

[2] V. G. Shobhana, N. Senthil, K. Kalpana et al., "Comparative studies on the iron and zinc contents estimation using atomic absorption spectrophotometer and grain staining techniques (prussian blue and DTZ) in maize germplasms," Journal of Plant Nutrition, vol. 36, no. 2, pp. 329-342, 2013.

[3] S. A. Deraniyagala, K. T. Mudalige, H. M. Anula, and M. Y. P. R. Jamburuthugoda, "Some micronutrient and macronutrient contents of some Sri Lanka food varieties," Vidyodaya Journal of Scinece, vol. 5, no. 1, pp. 93-102, 1994.

[4] G. Chathuranga, T. Balasuriya, and R. Perera, "Anaemia among female undergraduates residing in the hostels of University of Sri Jayewardenepura," Anemia, vol. 2014, Article ID 526308, 5 pages, 2014.

[5] S. A. Deraniyagala and P. S. Gunawardena, "Effects of cooking on the mineral and oxalate content of some legumes," Vidyodaya Journal of Science, vol. 8, pp. 39-49, 1999.

[6] M. E. Norhaizan and A. W. Nor Faizadatul Ain, "Determination of phytate, iron, zinc, calcium contents and their molar ratios in commonly consumed raw and prepared food in Malaysia," Malaysian Journal of Nutrition, vol. 15, no. 2, 2009.

[7] A. Rajbhandari and T. Subedi, "Spectrophotometric determination of total iron in rice and maize samples," Scientific World, vol. 11, no. 11, pp. 101-104, 2013.

[8] N. S. Lawal, N. Tajuddeen, and B. B. Garba, "Assessment of some mineral elements in different brands of powdered milk sold in Samaru Zaria, Nigeria," International Food Research Journal, vol. 22, no. 6, 2015.
[9] Survey Report-Assessment of Anaemia Status in Sri Lanka, Medical Research Institute of the Health Sciences, Ministry of Health, Nutrition and Welfare, Sri Lanka, 2001.

[10] T. Pedron, F. R. Segura, F. F. da Silva, A. L. de Souza, H. F. Maltez, and B. L. Batista, "Essential and non-essential elements in Brazilian infant food and other rice-based products frequently consumed by children and celiac population," Journal of Food Composition and Analysis, vol. 49, pp. 78-86, 2016.

[11] E. Pinto, A. Almeida, and I. M. Ferreira, "Essential and nonessential/toxic elements in rice available in the Portuguese and Spanish markets," Journal of Food Composition and Analysis, vol. 48, pp. 81-87, 2016.

[12] Nutrition Division Ministry of Health, Food Based Dietary Guidelines for Sri Lankans, Nutrition Division, Ministry of Health, Sri Lanka, 2nd edition, 2011.

[13] E. Damastuti, W. Y. N. Syahfitri, M. Santoso, and D. D. Lestiani, "Assessment of trace element daily intake based on consumption rate of foodstuffs in Bandung City," Atom Indonesia, vol. 38, no. 1, pp. 29-34, 2012.

[14] United States Department of Health and Human Services, Iron-Fact Sheet for Health Professionals, National Institute of Health, U.S., Department of Health and Human services, Washington, DC, USA, 2019, https://ods.od.nih.gov/ factsheets/Iron-HealthProfessional/\#en5.

[15] Medical Resaerch Institute, Recommended Daily Allowances for Sri Lankans, Department of Nutrition, Medical Resaerch Institute, Colombo, Sri Lanka, 2007.

[16] W. Y. N. Syahfitri, E. Damastuti, N. Adventini et al., "Essential minerals of rice in West Java Indonesia and its daily intake estimation," Atom Indonesia, vol. 44, no. 3, pp. 155-163, 2018.

[17] S. F. A. Bruggraber, T. P. E. Chapman, C. W. Thane, A. Olson, R. Jugdaohsingh, and J. J. Powell, "A re-analysis of the iron content of plant-based foods in the United Kingdom," British Journal of Nutrition, vol. 108, no. 12, pp. 2221-2228, 2012.

[18] Food Standards Agency, McCance and Widdowson's the Composition of Foods, Royal Society of Chemistry, Cambridge, UK, 6th edition, 2002.

[19] R. McCance and E. Widdowson, The Chemical Composition of Foods, His Majesty's Stationery Office, London, UK, 1940.

[20] A. M. Mayer, "Historical changes in the mineral content of fruits and vegetables," British Food Journal, vol. 99, no. 6, pp. 207-211, 1997.

[21] R. Narain and V. Ilango, "Analysis of iron content of selected vegetarian food items in Dubai, UAE," International Journal of Science, Environment and Technology, vol. 4, pp. 2278-3687, 2015.

[22] J. Gooneratne and S. C. Kumarapperuma, "In-vitro dialysability of iron in green leafy vegetables and seasonal variation of total iron content," Journal of the National Science Foundation of Sri Lanka, vol. 35, no. 1, p. 9, 2011.

[23] A. M. Karunaratne, P. H. Amerasinghe, V. M. Sadagopa Ramanujam, H. H. Sandstead, and P. A. J. Perera, "Zinc, iron and phytic acid levels of some popular foods consumed by rural children in Sri Lanka," Journal of Food Composition and Analysis, vol. 21, no. 6, pp. 481-488, 2008.

[24] M. Kumari, S. Gupta, A. J. Lakshmi, and J. Prakash, "Iron bioavailability in green leafy vegetables cooked in different utensils," Food Chemistry, vol. 86, no. 2, pp. 217-222, 2004.

[25] T. Anthoney Swamy, N. L. Kerubo, J. K. Obey, and M. Hillary, "Determination of iron content in selected indigenous green leafy vegetables in Baraton, Kenya," International Journal of Bioassays, vol. 5, no. 4, pp. 4500-4504, 2016.

[26] I. Wickramasinghe, K. K. D. S. Ranaweera, U. G. Chandrika, and A. Bamunaurachchi, "Content and in vitro availability of 
iron in cooked fish commonly consumed Sri Lanka," Journal of the National Science Foundation of Sri Lanka, vol. 36, no. 4, 2008.

[27] J. Liang, "Iron, zinc and phytic acid in rice from China: wet and dry processing towards improved mineral bioavailability," Doctoral Thesis, Wageningen University, Wageningen, Netherlands, 2007, https://www.researchgate.net/publication/40105304_Iron_ zinc_and_phytic_acid_in_rice_from_China_wet_and_dry_ processing_towards_improved_mineral_bioavailability.

[28] USDA National Nutrient Database, https://ndb.nal.usda.gov/ $\mathrm{ndb} /$.

[29] Ferralet, Mission Pharmacal Company, https://www.ferralet. $\mathrm{com} /$.

[30] V. Singh and A. N. Garg, "Availability of essential trace elements in Indian cereals, vegetables and spices using INAA and the contribution of spices to daily dietary intake," Food Chemistry, vol. 94, no. 1, pp. 81-89, 2006.

[31] A. E. Akpakpa, U. M. Eduok, D. S. Udiong, I. E. Udo, and A. I. Ntukuyoh, "Levels of metals in Kernels and shells of oil palm and coconut fruits," International Journal of Modern Chemistry, vol. 2, no. 1, pp. 20-27, 2012.

[32] D. C. M. B. Santos, L. S. B. Carvalho, D. C. Lima, D. J. Leão, L. S. G. Teixeira, and M. G. A. Korn, "Determination of micronutrient minerals in coconut milk by ICP OES after ultrasound-assisted extraction procedure," Journal of Food Composition and Analysis, vol. 34, no. 1, pp. 75-80, 2014.

[33] M. Hettiarachchi, C. Liyanage, R. Wickremasinghe, D. Hilmers, and S. Abrams, "Nutrient intake and growth of adolescents in southern Sri Lanka," Ceylon Medical Journal, vol. 51, no. 3, pp. 89-92, 2006.

[34] P. Niedzielski, M. Zielinska-Dawidziak, L. Kozak et al., "Determination of iron species in samples of iron-fortified food," Food Analytical Methods, vol. 7, no. 10, pp. 2023-2032, 2014.

[35] J. D. Cook, "Adaptation in iron metabolism," The American Journal of Clinical Nutrition, vol. 51, no. 2, pp. 301-308, 1990.

[36] T. H. Bothwell, R. W. Charlton, J. D. Cook, and C. A. Finch, Iron Absorption and Iron Metabolism in Man, Blackwell Scientific Publications, London, UK, 1989.

[37] H. C. Schonfeldt and N. G. Hall, " 8 th international food data conference," Journal of Food Composition and Analysis, vol. 24, no. 4-5, pp. 469-756, 2011.

[38] P. E. Adams, "Determining iron content in foods by spectrophotometry," Journal of Chemical Education, vol. 72, no. 7, p. 649, 1995. 


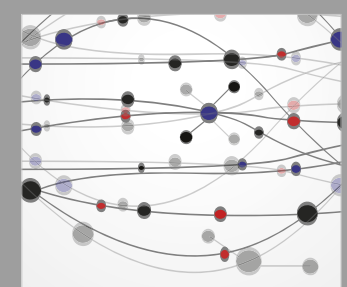

The Scientific World Journal
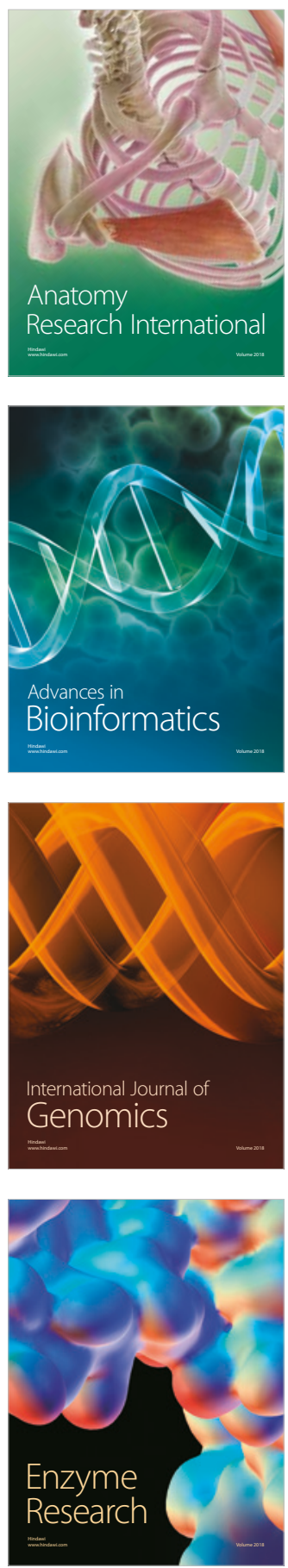
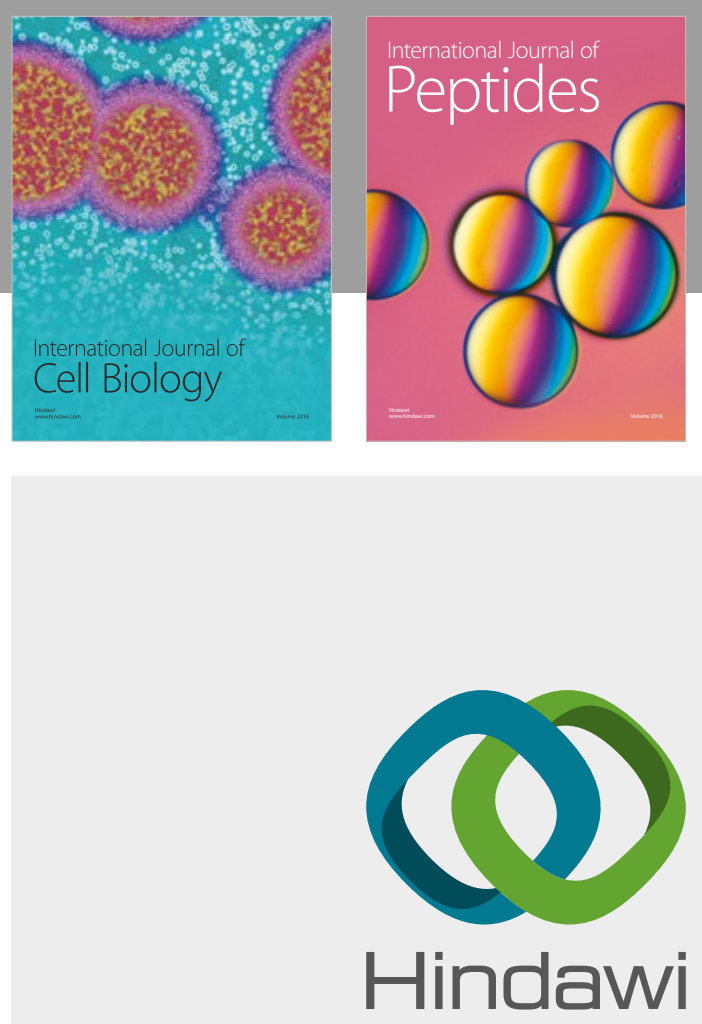

Submit your manuscripts at

www.hindawi.com
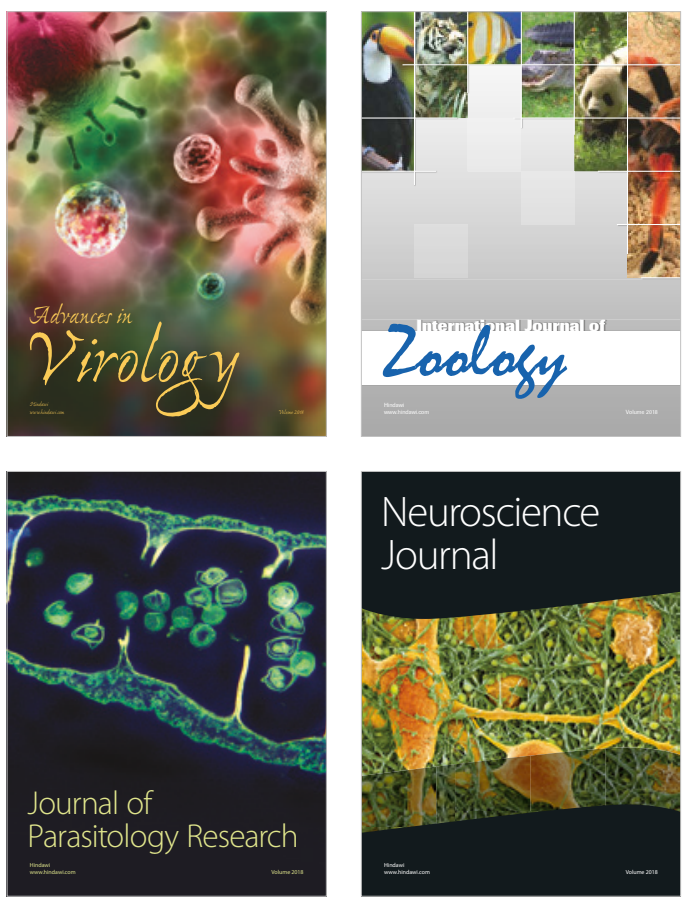
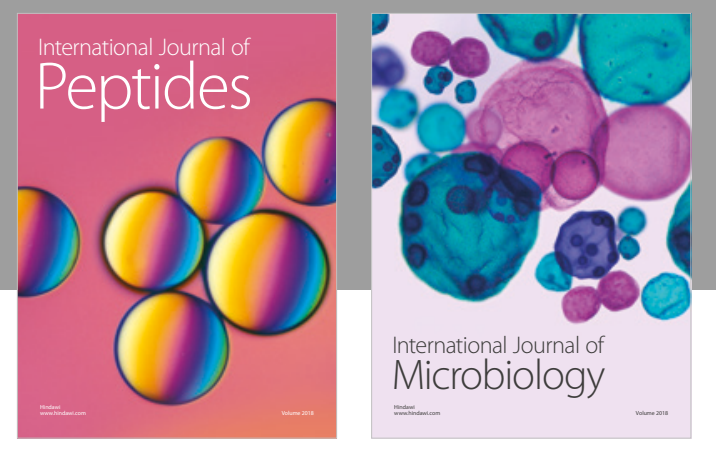

nternational Journal of Microbiology
Journal of
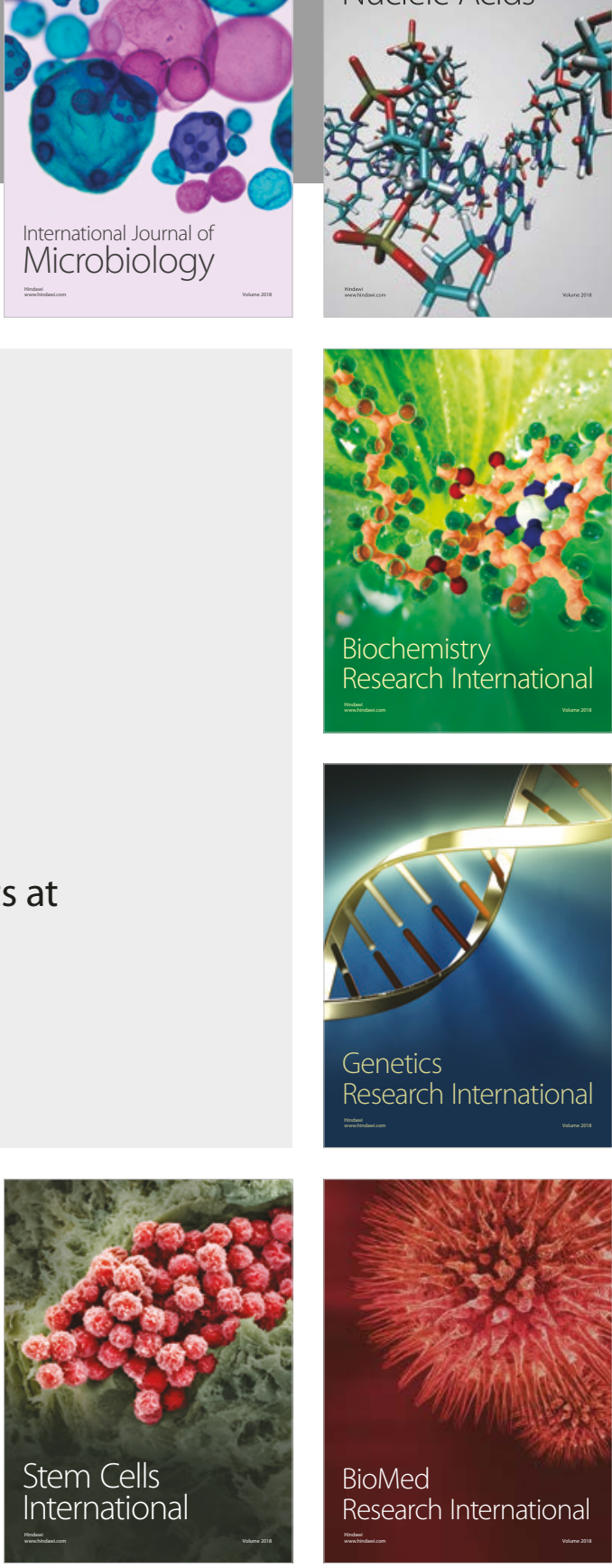
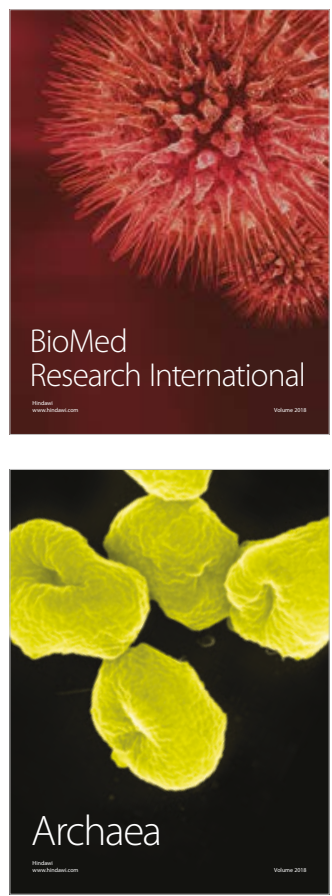